\title{
Lajos Vajda and the Russian Idea of Universalism
}

\author{
Lili Boros (boros.lili@uni-eszterhazy.hu) \\ Visual Art Institute, Károly Eszterházy University, Eger, Hungary
}

\begin{abstract}
This study focuses on the problem of interpreting Lajos Vajda's Icon Self-Portrait Pointing Upward (1936) while attempting to rethink the artist's relationship to the ideas of Russian religious philosopher Nikolai Berdyaev (1874-1948). In one of his letters dedicated to Júlia Richter, his future wife, Vajda wrote that Berdyaev's book entitled The New Middle Ages had greatly influenced his thinking. Through it, he became acquainted with the notion of universalism - the synthesis between East and West as part of a critique of Western individualism and positivism - which would gain in popularity in the early twentieth century. Based on the proximity between the dates of the letter and the time that Vajda formulated his so-called 'Szentendre Programme,' this article argues that the establishment of the Programme was directly influenced by Berdyaev's thinking. Consequently, it suggests that Icon Self-Portrait Pointing Upward can be read as a summary of Vajda's thoughts on culture as renewable through the synthesis of 'two types of European man.' From this perspective, Vajda's criticism of Western individualism leads to a re-thinking of his relationship both to European modernism and to conservative artistic and cultural ideas. This article connects all these broader questions to the interpretation of Icon Self-Portrait Pointing Upward, offering new directions in research into this enigmatic key work and masterpiece.
\end{abstract}

\section{Keywords}

Lajos Vajda; icons; Nikolai Berdyaev; Szentendre; universalism; Russian philosophy 


\section{Lajos Vajda and the Russian Idea of Universalism}

\section{Lili Boros}

\section{Introduction}

In 2018, the Ferenczy Museum Centre in Szentendre, Hungary, organized an exhibition on the interwar artist Lajos Vajda (1908-1941) with the title Between Worlds: The Life and Art of Lajos Vajda. ${ }^{1}$ It was the work of a research group that had been formed in 2016, including, among others, the Hungarian art historians Krisztina Passuth, Gábor Pataki and the author of this article. As a member of that group and of the museum staff, I began to research the problem posed by the interpretation of his painting Icon Self-Portrait Pointing Upward (1936) (Figure 1) which led me to rethink the artist's relationship to the ideas of Russian religious philosopher Nikolai Berdyaev (1874-1948). This article is based on a study published originally in Hungarian in the catalogue of the mentioned exhibition. ${ }^{2}$ It is already known that Vajda was interested in the writings of Berdyaev, but this article expands the existing tradition of scholarship in order to incorporate new points of view and to connect Berdyaev's influence - supportable by written documents - to the problems of interpretation associated with this specific painting, one of the most prominent works of Vajda's oeuvre. In particular, it goes beyond merely registering the fact of Berdyaev's influence and engages in a closer reading both of the painting and of Berdyaev's writings including, but not limited to, his major work The New Middle Ages (1924).

A very broad range of artists and art historians agree that Lajos Vajda was one of the most important Hungarian visual artists of the 1930s, but it is notable that he was unable to garner fame or recognition while alive. For the most part, his work only became influential following the Second World War thanks to the short-lived (1945-48) art group known as the European School (Európai iskola). He registered at the Hungarian Academy of Fine Arts in 1927, but without ever completing his studies, he first joined the left-wing creative community known as the Munka ('Work') circle in 1928, which had formed around Lajos Kassák, and then moved to Paris in 1930. After three and a half years spent there, he returned to Hungary in 1934 where he became involved in a right-wing creative milieu with Christian leanings. Together with his friend the painter Dezső Korniss (1908-1984), he formulated the so-called 'Szentendre Programme.' As part of the Programme - which he formulated in a letter to his future wife, Júlia, on 11 August 1936, and which will be referred to later - he and Korniss set out to collect sacred, architectural and everyday motifs from Szentendre, a former Serbian trading town

1) György Petőcz and Noémi Szabó, eds, Vajda Lajos. Világok között [Lajos Vajda: Between Worlds], Szentendre: Ferenczy Museum Centre, 2018.

2) Lili Boros, ‘Vajda és Bergyajev’ [Vajda and Berdyaev], in Petőcz and Szabó, eds, Vajda Lajos. Világok között, 226-233. 


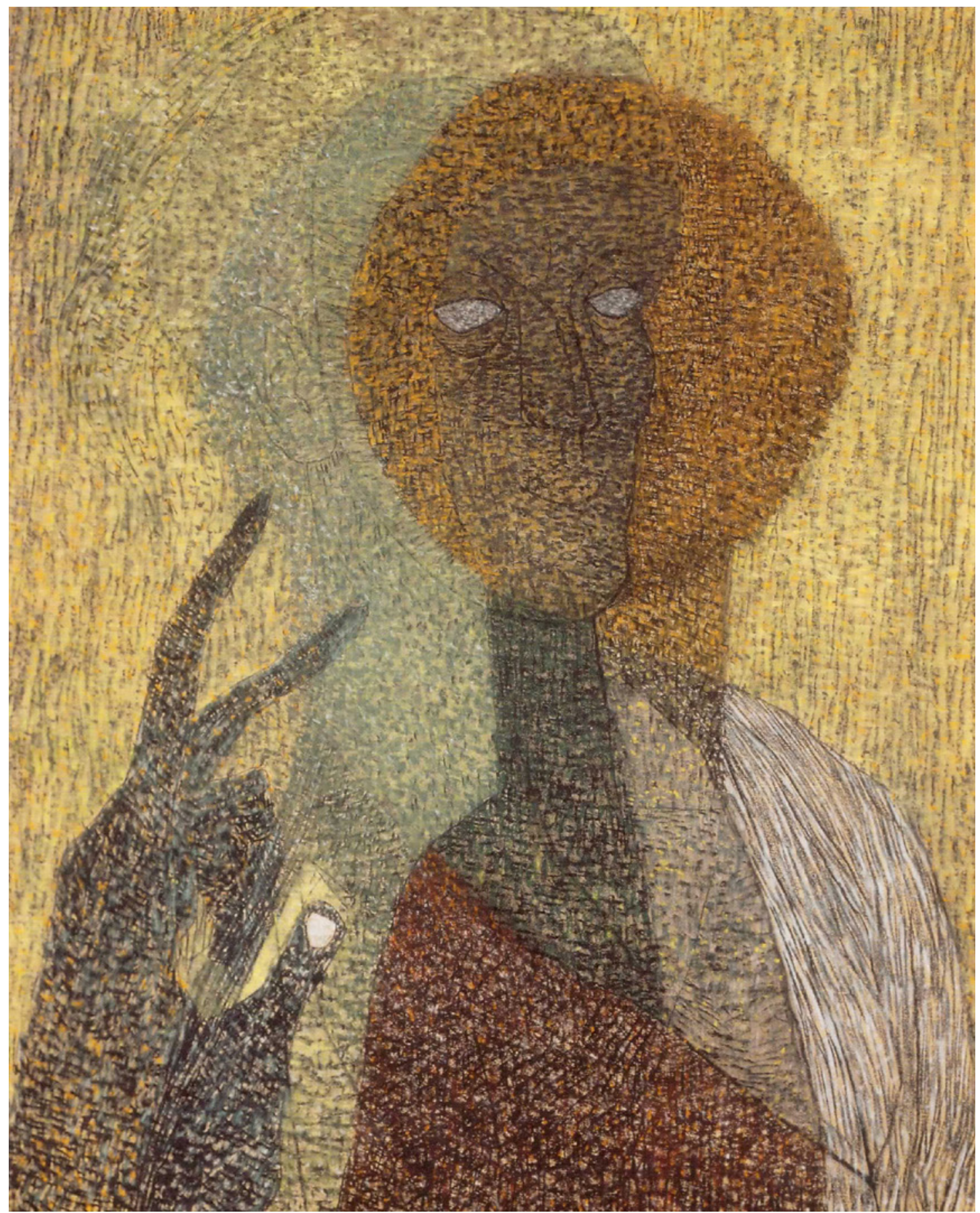

Figure 1: Lajos Vajda, Icon Self-Portrait Pointing Upward, 1936. Pastel on paper, $90 \times 62 \mathrm{~cm}$.

Kovács Gábor Art Foundation. Source: Wikimedia commons. 
on the Danube bank just north of Budapest, and its environs. The significance of this Serbian connection will become apparent later.

In the Programme Vajda and Korniss sought a path to modernity through the reinterpretation and mobilisation of tradition. There are obvious parallels here with the rejuvenation of European folk music that the Hungarian composers and collectors of folk music Béla Bartók (1881-1945) and Zoltán Kodály (1882-1967) undertook at the same time, seeking out and recording performances of folk music by rural musicians. Vajda thus took motifs from the original environment where they were discovered and superimposed them - in a similar fashion to the montage method popular in Paris at the time - in a transparent compositional system based on line drawing, so that he could explore their meanings in a new context. During the period between 1936 and 1937, the artist increasingly employed iconographic elements from Western and Eastern Christian visual culture, usually combined with other - sometimes Jewish - motifs, even in his transparent line drawings such as Madonna Torso with Jewish Egg Motif (1936). The 'icon' works from this period followed a reductive mode of representation, conceived in the Byzantine and orthodox spirit, of which Icon Self-Portrait (1936) (Figure 2) is a clear example. Icon Self-Portrait Pointing Upward combines Vajda's transparent line drawings with his interest in the art of icons. It is the crowning achievement of this period, a significant work from his oeuvre that represents the fullest synthesis of his ideas at that time. It is also an enigmatic painting, which has made it one of the most analysed images in Hungarian art history.

Vajda drew on a number of literary sources, but it was the work of Nikolai Berdyaev above all that was most important for him. The influence of, in particular, Berdyaev's book The New Middle Ages (1924) on Vajda's thought and work is well attested and is more than a mere hypothesis; in one of his letters, Vajda himself emphasised its importance. ${ }^{3}$ In addition, if we approach The New Middle Ages alongside the thought of another notable Russian thinker, the philosopher and theologian Vladimir Solovyov (1853-1900), we can see how specific philosophical and artistic ideas that were widespread in the late nineteenth and early twentieth centuries made their way into Vajda's art. Having explored this broad conceptual background, we can then consider how Vajda's Icon Self-Portrait Pointing Upward (1936) can be interpreted in light of the idea, expressed by Berdyaev, of the decline of Western culture, which he combined with a belief in the creation of a new (cultural) European unity, based on a synthesis of East and West.

Icon Self-Portrait Pointing Upward can thus be seen as a summation of Berdyaev's view of the fall of Western culture and a synthesis of the East and the West. The triadic character of the figure, with a third form emerging out of the synthesis of the 'realistic' and 'abstract' portraits, can also be viewed as a presentation of the 'Szentendre Programme's call for a culture created anew from such the duality of East and West and out of the unification of the 'two different types of European human being. ${ }^{4}$

It would be erroneous, however, to emphasize Berdyaev's influence alone, as works connected to the icon period in Vajda's career also indicate he had interest in, and familiarity with, the

3) Vera Jakovits and Gyula Kozák, eds, Vajda Lajos levelei feleségéhez, Vajda Júliához, 1936-1941 [Lajos Vajda's Letters to His Wife, Júlia Vajda, 1936-1941], Szentendre: Erdész Galéria, 1996, 26, 28.

4) Vajda, Letter to his wife, 11 August 1936 in Vera Jakovits and Gyula Kozák, eds, Vajda Lajos levelei feleségéhez, 36. 


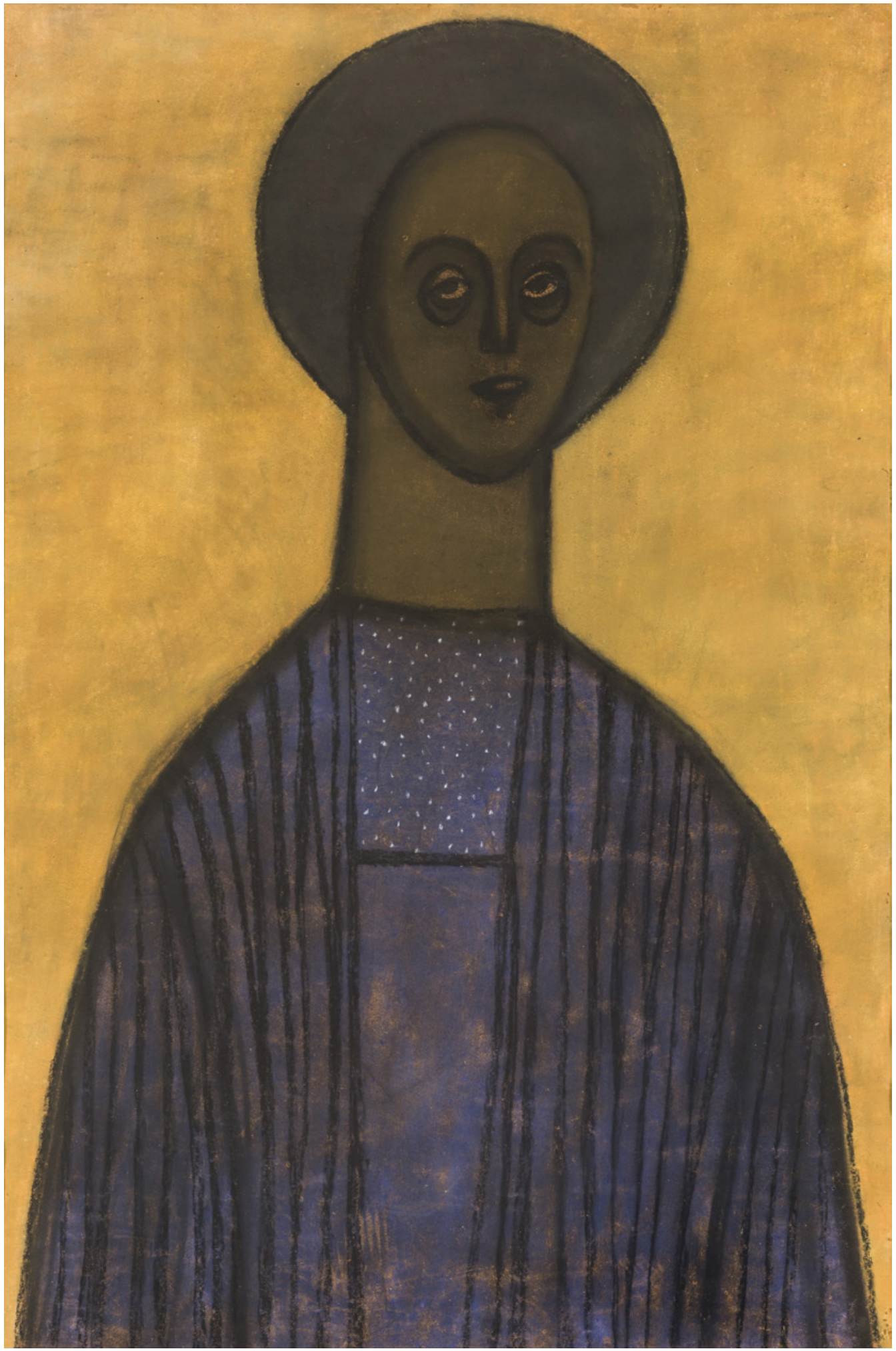

Figure 2: Lajos Vajda, Icon Self-Portrait, 1936. Pastel on paper, 90 x $60 \mathrm{~cm}$. Szentendre: Ferenczy Museum Centre. 
theoretical works of the philosophers Martin Buber (1878-1965) and Ferdinand Ebner (18821931). Vajda's work was also shaped by a number of Hungarian influences, including the ideas of his friend Lajos Szabó (1902-1967), a philosopher and founder of the Budapest Dialogical School, and Béla Tábor (1907-1992), Szabó's friend, colleague, and co-author of the book Indictment Against the Spirit (1936). ${ }^{5}$ These latter connections are well known and documented in the literature on Vajda. Nevertheless, it is the figure and thoughts of Berdyaev that are of crucial significance; bringing him into the discussion expands the tradition of interpretation and helps address problems of understanding raised by Icon Self-Portrait Pointing Upward. ${ }^{6}$

\section{Vajda and Berdyaev}

In September 1936, Lajos Vajda wrote: 'One person, culture or civilisation fertilises the other - this is the law of life.' The 'Szentendre Programme' he and Korniss formulated was a result of this same belief in the interconnections between cultures coupled with a dualistic view of East and West:

I, from the West, culturally tend toward Russia and Serbia (in other words, toward the East). Korniss, however, who comes from the East, is oriented toward France and the Netherlands (where he lived for a while as a child). From all this, it is evidently clear that our endeavours are aimed at establishing a Central and Eastern European art - with influences from the two great European centres of culture, the French and the Russian. The (geographical) position of Hungary in Europe is such that it is predestined to connect the West (French) and the East (Russian): we wish to fuse back together that which, at these two poles, culturally (in art) signifies the expression of the two different types of European human being [my emphasis - L. B.]. We wish to be the builders of bridges: Hungary forms a bridge between East and West, North and South. ${ }^{8}$

5) The philosopher Lajos Szabó travelled to Paris. Upon meeting Vajda there he recognised in him a 'kindred spirited innovator.' Szabó and Béla Tábor were advocates of dialogic thinking in keeping with the formulations of Martin Buber and Ferdinand Ebner. Zsolt K. Horváth, ‘Szubkultúrák forrásvidékén’ [In the Headwaters of Subcultures], Fordulat, 7, 2009, 58-59. Cf. Stefánia Mándy, Vajda Lajos [Lajos Vajda], Budapest: Corvina Kiadó, 1983, 173. Much of the intellectual milieu in the Hungary of the interwar period was defined, especially in the 1920s, by an outlook based on Oswald Spengler's philosophy, which emphasised the crisis of European culture. On this, see György Petőcz's interpretation in Krisztina Passuth and György Petőcz, Ki a katakombából [Out of the Catacomb], Budapest: Noran Libro, 2016, $185-192$.

6) Vajda's painting has also been described as having a 'polyphonic' and 'dialogical' character, which also provides a key to its interpretation and resolves the decades-long debate surrounding its meaning. The connection between Mikhail Bakhtin's theory of dialogism and polyphony - which he developed based on his reading Dostoyevsky - and Lajos Vajda's oeuvre has been explored in particular by Stefánia Mándy. See Mándy, Vajda Lajos, 123. In the literature on Vajda this train of thought was not picked up again, however, although works by Dostoyevsky, such as The Idiot and The House of the Dead, can also be found in the reading list Vajda compiled. The reading list is published in Judit Radák, Vajda Lajos Pepita füzetei [Lajos Vajda's Chequered Notebooks], Budapest: Loránd Eötvös University PhD Dissertation, 2013, 158.

7) Lajos Vajda, Letter to Júlia of 3 September 1936, in Vera Jakovits and Gyula Kozák, eds, Vajda Lajos leveleifeleségéhez, 46. All of the quotations from these letters published in this article were translated from Hungarian to English by Zsófia Rudnay.

8) Lajos Vajda, Letter to Júlia of 11 August 1936, in Jakovits and Kozák, eds, Vajda Lajos levelei feleségéhez, 36. 
This idea was clearly illustrated by a 'map', found in the same letter, written in August of 1936. To Vajda, European unity was, first and foremost, a question not of the philosophy of religion, but of art, leading directly to the (millennia-old) problematic of the representability of divine and human essence.

This paradigm of a dichotomy was borrowed from Berdyaev and had its antecedents in the traditions of Russian philosophy and literature: the idea of Western individualism versus the Russian principle of collectivism, of 'artificial' Western society versus and 'natural' Russian society, originated in the eighteenth century and came to a climax in the disputes between Westernisers and Slavophiles in the $19^{\text {th }}$ century. Based on the material Lajos Vajda is known to have been reading, it was not only through the work of Berdyaev that he encountered this conception; he most likely also this came across it in his reading of the literary works of Russian authors such as Alexander Pushkin (1799-1837), Nikolai Chernyshevsky (1828-1889), Nikolai Gogol (1809-1852) and Fyodor Dostoyevsky (1821-1881), as well as the philosophical writings of Vladimir Solovyov (1853-1900). ${ }^{9}$

The titles of books by Solovyov and Berdyaev were recorded in the small-format Chequered Notebook, which he began using between 1936 and 1938. ${ }^{10}$ Indeed, he listed six titles from the German edition of the 1920s of Solovyov's writings, including The Meaning of Love, The Meaning of the War and The Spiritual Basis of Life. ${ }^{11}$ In spite of this fact, we find no references to Solovyov in scholarship on Vajda - even though the idea of (Christian) universalism is first and foremost linked to him, and was only made current by Nikolai Berdyaev a good twenty years later. On the other hand, given that Solovyov is not mentioned in any of Vajda's letters, we have no reason to doubt that Berdyaev was indeed of more significance to Vajda, who most probably learned about Solovyov and his works through Berdyaev's writings.

It is almost certain that Vajda read Berdyaev's The New Middle Ages in Hungarian since, in the reading list he compiled, it is the Hungarian edition that is listed (Figure 3 ). ${ }^{12}$ It has been confirmed by Vajda's biographer, Stefánia Mándy, that around 1936 he picked up 'probably the only Berdyaev work that had been translated to Hungarian, The New Middle Ages. Published in Hungarian in 1934, in its own day, the book must have, in certain respects, given the impression of a utopia of the religious spirit.' ${ }^{13}$ We know from the correspondence between Vajda and his wife Júlia, as well as from the biographical notes of Júlia, that the artist was introduced to Berdyaev's writing by the philosopher Lajos Szabó (1902-1967). As Júlia stated: 'He had met Lajos Szabó in Paris, in 1933. (...) at the same time, he was an avid reader and was greatly influenced by Berdyaev's philosophy, among others. He fully believed that we were on the brink of "the new middle ages"; that the world and humanity could only

9) Radák, Vajda Lajos Pepita füzetei, 18.

10) Ibid, 30.

11) Vajda listed the following titles: Die nationale Frage im Lichte der Sittlichkeit (1920), Der Sinn des Krieges (1920), Drei Reden zum Andenken Dostojevskij gewidmet (1921), Die geistlichen Grundlagen des Lebens (1922); Geschichts-Philosophie (1928), Der Sinn der Liebe (1930). See Radák, Vajda Lajos Pepita füzetei, 156.

12) Vajda's bibliography contains this edition, as well as Berdyaev's Der Sinn der Geschichte, published in Darmstadt in 1925. Radák, Vajda Lajos Pepita füzetei, 156.

13) Mándy, Vajda Lajos, 77. 
be saved by a great religious rejuvenation.'14 In a letter written to Júlia when still his financée Vajda noted: 'the era of secular monkhood has once again arrived. (Berdyaev, too, says this, only he gives it a deeper and more beautiful articulation in his book The New Middle Ages, which Szabó has lent to me.)"15 He added: 'We had many discussions about Berdyaev (Russian emigrant philosopher of religion), in whom we are both equally interested. ${ }^{16}$ At this point, Vajda was interested in cultures where he felt a sense of community - that is to say the force to create form (he noted, for example, 'I seek to unveil the secret, abstract essence of things'). ${ }^{17}$

For Vajda the desire for spiritual community signified not only an interest in the disappearing world of rural existence, but also a commitment to icon painting, which manifested itself primarily in structural composition, form and colour, 'and especially in the sense of nostalgia for the way of life that underlay, and gave rise to, them,' as Endre Bálint has put it. ${ }^{18}$ The religious commitment underpinning this is clear: in 1943 his wife Júlia wrote: 'During his icon period, he fantasised about placing his works on the wall, like on an iconostasis. ${ }^{19}$ He saw Malevich, Kandinsky, Klee and Picasso, too, as representatives of the same collective ideal, and also viewed the Bauhaus in this light. To quote Júlia on Vajda: 'I feel it's pointless arguing with him; to him, the workings of the Bauhaus evidenced a purity of aspiration - beyond appreciating it for its revolutionary novelty, he saw it as a manifestation of the collective spirit. He sought the spirit of collectivity in everything - the signs of a religion newly forming in our era. ${ }^{20}$

Paris seems to have been central to Vajda's adoption of such spiritualist ideas. Berdyaev was living in the city at the same time that Szabó and Vajda were in the city. There he was occupied editing works and periodicals on the philosophy of religion. We have no information as to whether Szabó or Vajda met Berdyaev personally, but one might speculate that this may have happened and may be one of the reasons for the painter's later interest in the philosopher. It is also possible that it was there, too, that Vajda encountered the periodical Put' [Path], which was edited by Berdyaev and published in Paris.

Nikolai Berdyaev was one of the most significant representatives of Russian Christian existentialist philosophy. After being forced to leave his home country in 1922, he moved first to Berlin, and then, in 1923, to Paris, where he became a prominent figure in emigré circles. His dualistic theory was deeply rooted in the traditions of Russian thinking about cultural history, where a dichotomised view of culture and history was brought to the foreground, partly in response to the reforms introduced by Peter the Great (1682-1725). This dichotomy manifested itself in the oppositions between the foreign and the native, and the urban and

14) Júlia Vajda’s biographical notes about Lajos Vajda, quoted by Stefánia Mándy, Vajda Lajos, 172. Cf. Júlia Vajda's note (p. 172): 'While I was a Marxist, he talked about the coming of a new middle ages. At some point, he, too, had been a Socialist, but now he believed in the realisation of the collective idea through religious renewal. (...) He looked for the collective spirit in everything, the signs of a new religion forming in our era.'

15) Letter to Júlia, Summer 1936, in Jakovits and Kozák, eds, Vajda Lajos levelei feleségéhez, 26.

16) Letter to Júlia, 9 June 1936, in Jakovits and Kozák, eds, Vajda Lajos levelei feleségéhez, 28.

17) Letter to Júlia, 23 July 1936, in Jakovits and Kozák, eds, Vajda Lajos levelei feleségéhez, 31.

18) Endre Bálint, A remény négyfelé szakadt. Válogatott írások [Hope was Torn into Four: Selected Writings], ed., Katalin Mezey, Budapest: Széphalom Könyvműhely, 2015, 147.

19) Notes on Lajos Vajda, written by Júlia Vajda in 1943, is published in Stefánia Mándy, Vajda Lajos, 172.

20) Júlia Vajda, Jegyzetek Kállai Ernőnek Vajda Lajosról [Notes on Lajos Vajda to Ernő Kállai]. Unpublished notebook. The notebook is currently in a private collection. 
the rural, as well as in a critique of the mechanical adoption of Western cultural values and practices. ${ }^{21}$ Notions associated with the belief that Russia had a religious mission, coupled with criticism of European society, also originated in the eighteenth century. The critique of Western positivism was already discussed in one of Solovyov's early works, The Crisis of Western Philosophy, first published in $1874 .^{22}$ He believed that an atheistic civilisation alienated from God could only restore its faith in humanity through the unifying culture of Christianity. The fundamental principle of his philosophy was pan-unity (vseyedinstvo), which he outlined in his Lectures on Divine Humanity (1877-1881), and which was closely linked to the Slavophiles' principle of congregation (sobornost). ${ }^{23}$ 'Congregation' signifies more than a mere gathering together of a group of people; the sobor is a sacred spiritual community, which represents the unity of the faithful who are devoted to the body of Christ. This principle also appeared in Berdyaev's philosophy as the opposite of the Western notion of individualism: 'the Church is the cosmos christologised,' he argued, 'sobornost represents the opposite of both Catholic authoritarianism and Protestant individualism.24

Berdyaev's book The New Middle Ages was first published in Russian in Berlin in $1924 .{ }^{25}$ It was quickly translated into French and German in 1927 and then, in 1935, into Hungarian; the symbols of sickle, hammer and cross which appear on the cover page of the Hungarian edition are worth noting (Figure 3). ${ }^{26}$

The 'new Middle Ages' referred to in the title constitutes a way out of world crisis - that is to say, the exhaustion of nineteenth-century culture as heir to the legacy of ancient civilisation. ${ }^{27}$ For Berdyaev, the industrial capitalism of the modern age was individualistic and atomistic and the idea of universalism had lost its significance. In this paradigm of Eurasian cultural history, a universalism that realises Christian unity would overcome national character; people were to embody the idea of homo universalis. ${ }^{28}$ The task of realising this unification

21) The exploration of the traditions of Russian cultural history, fine arts, philosophy of religion, and fine literature, including Dostoyevsky's poetry and Bakhtin's theory of dialogism, in Vajda's oeuvre has been most comprehensively worked out - and emphasised in its significance - by Stefánia Mándy. See Mándy, Vajda Lajos, 85-86 and 122-124. This is not exactly surprising since, as a translator of literary works, Mándy had an excellent grasp of Russian. In addition to Poltoratsky and Krylov, she also translated Viktor N. Lazarev's Studies in Byzantine Painting into Hungarian, together with Béla Tábor. See Viktor Lazarev, Bizánci festészet [Byzantine Painting], trans. Béla Tábor and Stefánia T. Mándy, Budapest: Magyar Helikon, 1979.

22) Vladimir Sergeyevich Solovyov, The Crisis of Western Philosophy: Against the Positivists, trans. Boris Jakim, Hudson, N.Y. : Lindisfarne Press, 1996. The text was his Master's thesis and was first published as Кризис западной философии, St. Petersburg: St. Petersburg University Press, 1874.

23) Zoltán Hajnády, Sophia és Logosz. Az orosz kultúra paradigmatikus-szintagmatikus rendszere [Sophia and Logos. Paradigmatic-Syntagmatic Structure of Russian Culture], Debrecen: Kossuth University Press, 2002, 184.

24) In his work entitled The Meaning of History, Berdyaev describes 'sobornost' not as collectivism, but as an experiment in creating that which is new and the organic. Quoted in Zoltán Hajnády, Sophia és Logosz, 185.

25) Published as Новое средневековъе: Размышление о судьбе России, Berlin: Obelisk, 1924.

26) Nikolai Berdiaeff, Un nouveau moyen âge: réflexions sur les destinées de la Russie et de l'Europe, trans. A. M. F., Paris: Plon, 1927; Nikolai Berdjajew, Das neue Mittelalter: Betrachtungen über das Schicksal Russlands und Europas, trans. Alexander Kresling, Darmstadt: Reichl, 1927. Berdyaev's book was published in Hungarian as Az uj középkor: Szemlélődések Oroszország és Európa sorsán [The New Middle Ages: Pondering the Fate of Russia and Europe] and included three studies: 'Az uj középkor,' 'Az orosz forradalom,' ‘Demokrácia, szocializmus, theokrácia' [The New Middle Ages; The Russian Revolution; and Democracy, Socialism, Theocracy]. Nyikolaj Bergyajev, Az uj középkor, trans. János Lotz and Géza Sebestyén, Budapest: Pro Christo Diákszövetség Szövétnek Kiadóhivatala, 1935.

27) Nyikolaj Bergyajev, $A z$ uj középkor [The New Middle Ages], 13.

28) Ibid., 34. 


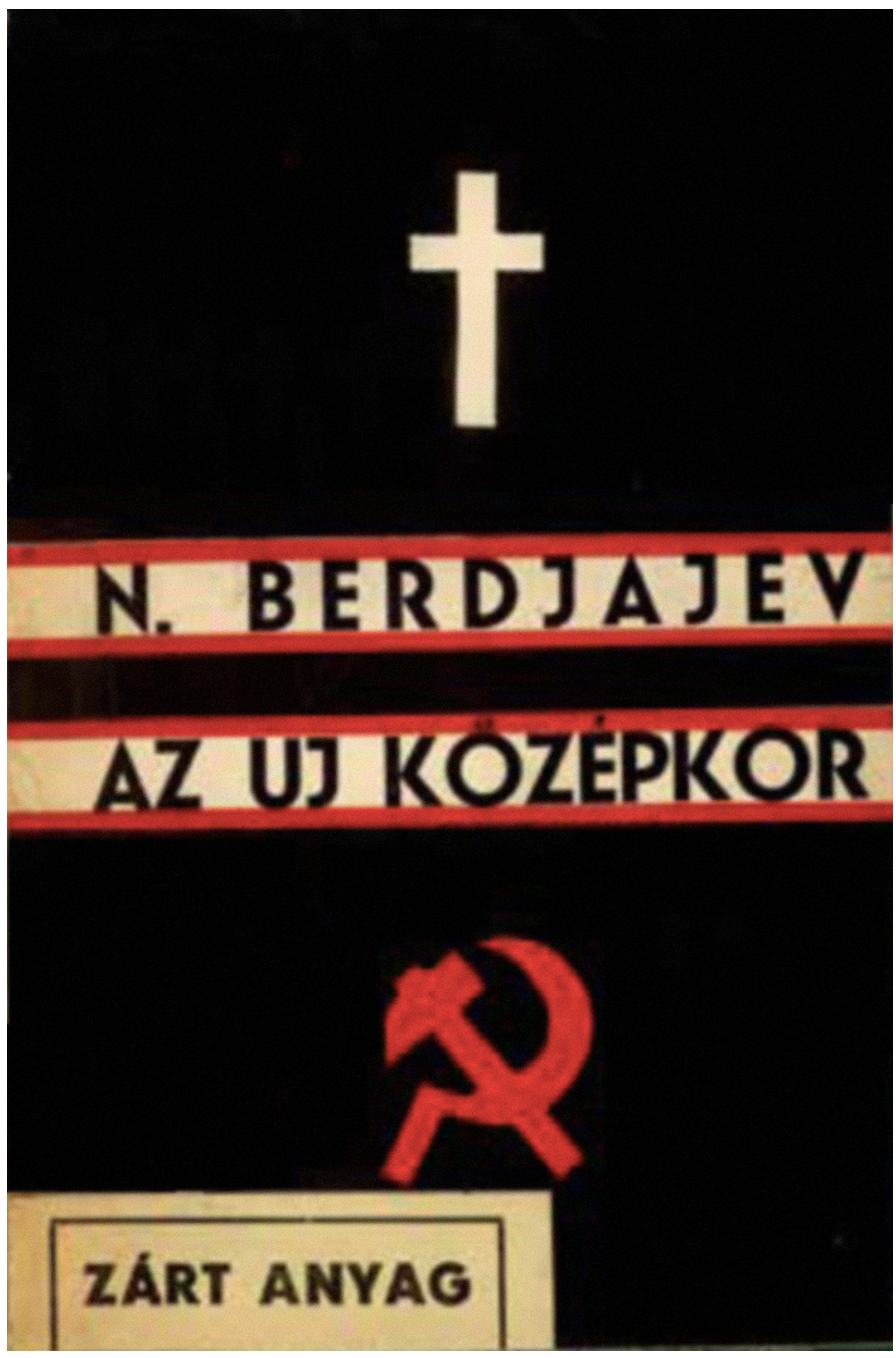

Figure 3: Cover of Nikolai Berdyaev's book The New Middle Ages, 1935.

Budapest: National Széchényi Library.

of the world fell to the Russian people, however, as the Russian soul stood closest to the pan-human and to universalism. As Berdyaev argued in his text The Fate of Russia (published in 1918, six years before The New Middle Ages), in medieval times Europe lived in a unified religious spirit, but then this organic unity based on tradition and religious principles had been lost with the rise of humanism, and especially the Protestant Reformation. ${ }^{29}$ This view of Russian culture set in opposition to that of Western Europe was rooted in the Slavophilic tradition. Berdyaev, however, spoke not of the superiority of Eastern culture, but of a culture that integrated the East and the West, with Russia playing a privileged role in making this a reality. ${ }^{30}$

29) Berdyaev, Судъба России (Опыты по психологии войны и национальности), Moscow: Leman and Sakharov, 1918.

30) In spite of the fact that he builds on the traditions of Slavophilic and Western Enlightenment thinking, he rejects both, while the Eurasian ideal of unifying the cultures of the East and the West, shared by both groups - does appear 
This system of thought, and especially the principles of 'sobornost' and homo universalis, may be connected to Vajda's so-called icon period of the 1930s, as well as to his self-portraits created between 1934 and 1937. An additional important element was Berdyaev's idea of theurgy, exploring the relationship of people to each another and to the gods. Artists are meant to facilitate the divination of the human being - that is to say, the artist is the one who shapes that which is divine into something human and that which is human into the divine.$^{31}$ Berdyaev writes: 'This deification or theosis, which is a fundamental characteristic of Pravoslavian mysticism, is neither a monistic identification with God, nor a humbling of the human being and the created world. Theosis renders human beings divine, while still maintaining their human nature. ${ }^{32}$

Vajda's human- and self-representation related to the abstract approach and visual language of icon painting in that it conveyed the idea of the individual person dissolving into the community - homo universalis. The visual language of icons was, for him, a new context, a closed intellectual construct that gave forms a new kind of symbolic value. ${ }^{33}$ For Anikó Faludy, who sees the formal characteristics and compositional structure of icons not only in the works of the artist's icon period, but also in his Paris montages, Vajda endeavoured, like medieval artists, to render tangible that which is intangible, or, to put it differently, to represent the unpresentable. ${ }^{34}$ During his icon period, as Gábor Pataki points out, the artist was preoccupied with the 'representability of the divine image.'35

If we consider the history of research centred on Vajda, Gábor Pataki and György Petőcz have both not only emphasised Berdyaev's influence, but also make his thoughts an integral part of the interpretation of Icon Self-Portrait Pointing Upward. ${ }^{36}$ The scale of this study does not allow for extended discussion of the history of research into this work. Here, I can only refer to those interpretations that touch on - or at least bring up the possibility of - readings that stress the importance of Berdyaev, although these interpretations are based not on The New Middle Ages, but on other texts by the philosopher (for instance: his book on Communism titled The Meaning of History, which can also be found in Vajda's reading list, has served as an important source). ${ }^{37}$ Pataki identifies the third face in the painting - born of the constellation of the 'realistic' (human) and 'iconic' (divine) figures - as the God-Man or Theanthropos, ultimately connecting it to an iconography that is closer in type to Christ Emmanuel, than to Christ

in his writing. Olga Szűcs, ‘Az orosz történetem sajátosságai N. A. Bergyajev korai műveiben’ [The Characteristics of Russian History in N. A. Berdyaev's Early Works], in Magdolna Ágoston, ed., Tanulmányok Oroszország múltjából [Studies in the Russian Past], Szombathely: NyME Savaria Egyetemi Központ, 2008, 133-134.

31) Hajnády, Sophia és Logosz, 209 and 230.

32) Quoted in ibid., 230.

33) Éva Körner, ‘Hozzászólás a "Szentendrei művészet” fogalom kérdéséhez’ [Comments on the Question of the Concept of 'Szentendre Art'], Müvészettörténeti Értesitō, 14:2, 1965, 228.

34) Anikó Faludy, 'Vajda Lajos és az ikonok' [Lajos Vajda and the Icons], Müvészet, 21:1, 1980, 19.

35) Gábor Pataki, 'Párduc és liliom. Vajda Lajos kiállítása' [Panther and Lilies: Exhibition of Lajos Vajda], in Nóra Veszprémi, ed., Vajda. Vajda Lajos kiállitása [Vajda: Exhibition of Lajos Vajda], Budapest: Hungarian National Gallery, 2008, 10.

36) Gábor Pataki, 'Vajda Lajos: Felmutató ikonos önarckép' [Lajos Vajda: Icon Self-Portrait Pointing Upward], Ars Hungarica, 28:1, 2000, 157-168; György Petőcz, 'A Felmutató titkai' [Secrets of Icon Self-Portrait Pointing Upward], Beszélő, 17 February 2014. http://beszelo.c3.hu/galleytext/a-felmutato-titkai-petocz-gyorgy-tanulmanya (Last accessed: 10. 11. 2019.).

37) Radák, Vajda Lajos Pepita füzetei, 156. 
Pantocrator. ${ }^{38}$ In Pataki's interpretation, the threefold face, with the third face emerging from the overlapping of the 'realistic' depiction containing the features of Vajda's self-portrait and an abstracted 'spherical head,' invokes Berdyaev's trichotomic understanding of the person as body, soul and spirit, and his concept of God-God-man. For Pataki it also indicates the influence on Vajda's thinking of Martin Buber's notion of I-Thou-It. ${ }^{39}$ The ghostly face arising from the blend of the human and the divine thus becomes Vajda's 'real' self-portrait. ${ }^{40}$ György Petőcz, who is credited with presenting the most comprehensive summary of the existing interpretive versions of Vajda's Icon Self-Portrait Pointing Upward, argues that it was Berdyaev who sparked Vajda's interest in icons. Petőcz also points out that even before reading The New Middle Ages, Vajda 'had been thinking in a similar vein,' with Berdyaev subsequently inspiring his turn in this direction. ${ }^{41}$ Recently, Ferenc Gosztonyi, in reference to my own attempt at re-thinking the interpretation of this piece, has suggested that the work should be regarded as a type of self-portrait. For Gosztonyi the theme of the work is the transformation of the (individual) human portrait into the (self-)portrait of the nameless (non-individualised) artist, the modern painter of icons. ${ }^{42}$

Katalin Kemény, in an essay titled 'Face-Mask-Icon,' had already anticipated the above critical interpretations to some extent. The reason I mention her last is because her approach stands closest to the interpretive focus of this article. Kemény regards Vajda as seeing his work as acheiropoietos, that is to say, in the original sense of the word in Christian theology, written 'not with his own hand,' but by a higher agency: 'The purpose of meditating before an icon is to shed the I that exists in time, and, while inhabiting an 'older' self, to identify with an accessible, ancient ancestor. ${ }^{\prime 3}$ The basis of icon painting is Christ's incarnation (as the ultimate theological reasoning of iconodules), the appearance of the universal human being, and God's identification with humanity through Christ. 'The object, figure, inspirer of Christian art is the transfiguration of the person; the manifestation of eidos through body, form, and intellect. (...) And why it would be pointing upward, when it points neither beyond itself toward the sky, nor downward to the depths, but instead (...) turns questioningly toward (...) the face. ${ }^{44}$

38) Gábor Pataki, ‘Vajda Lajos: Felmutató ikonos önarckép’' 166-167. Because, in the interest of keeping to my focus, the scope of this study is limited, it is not possible to cover the full research history and range of interpretational directions of Icon Self-Portrait Pointing Upward; I only highlight a few aspects that are related to Berdyaevian thought. Furthermore, I also refrain from discussing the issues surrounding the naming of Vajda's work; for the sake of simplicity I use the title that is most often used with reference to it (Icon Self-Portrait Pointing Upward).

39) Martin Buber, Ich und du, Leipzig: Insel-Verlag, 1923.

40) Gábor Pataki, 'Párduc és liliom. Vajda Lajos kiállítása,' 11.

41) György Petőcz, 'A Felmutató titkai.'

42) Ferenc Gosztonyi, "Vajda Lajos művészete 1936-ban: Szempontok a "konstruktív-szürrealista tematika" és a Felmutató ikonos önarckép értelmezéséhez' [The Art of Lajos Vajda in 1936: Ways of Interpreting His 'Constructive Surrealist Themes' and the Work Entitled Icon Self-Portrait Pointing Upward], Ars Hungarica, 45:1, 2019, 127-141.

43) Katalin Kemény, Maszk és valóság [Mask and Reality], Budapest: Ernst Museum, 2007, 41.

44) Ibid., 41-43. 


\section{Icon Self-Portrait Pointing Upward}

Reflecting the ideologies of Solovyov, and, later, Berdyaev, the work shows two faces, representing two different traditions of representation, as well as two distinct visual languages and conceptualisations of the human being. That the 'realistic' face constitutes a self-portrait can be confirmed by its similarity to a number of other such images; the arc of the hairline beginning at the ears and finishing at the brow ridge, the double line and shape of the nose, as well as the circular lines under the eyes, also appear in, for example, Self-Portrait with Loose Shirt Collar (1935) his Self-Portrait with Skull (1936) (Figure 4) or Self-Portrait with Architecture (1936-1937). ${ }^{45}$ The frontally oriented icon figure is also a self-portrait (cf. Icon Self-Portrait, Figure 2). At the same time, the identification of the images as self-portraits has been disputed and it is certainly true that we can see elements on the sides of the 'realistic' face to the left that are not characteristic of these representations: the mane of hair originates from the contour line of plain hair, and then dissolves into the 'furrowed' background. The face, bearing features reminiscent of other self-portraits, is transformed into a pronounced male portrait that borders on the antique. Perhaps it is no exaggeration to say that, in Solovyov's (and, through him, Berdyaev's) idea of theurgy, which also defines the fundamental role of artists, we are witnessing not only the process of human divination, but also the development of a kind of self-portrait as Christ, as it dissolves and disappears in the duality of the figure that embodies both the principle of the individualised human being and that of sobornost. For, as Berdyaev stated, that which has been split in two can only be reunified in Christ. For these reasons, the depiction has multiple potential meanings, and the image is difficult to describe, since the boundaries of its forms are not clearly defined. This is probably why it also has been referred to as a 'narrative' work, although the narrative is itself unclear.

The Christological significance of the middle face, created through the unification of the other two, is also supported by a number of analogies with icon painting, reproductions of which Vajda most likely come across; his reading list certainly included books on Byzantine, Bulgarian and Russian icon painting. His interest was undoubtedly also shaped by the character of Szentendre, where Vajda lived. For it was a small multicultural town that had preserved Serbian orthodox traditions due to the Serbian population that had historically lived there with. Amongst the volumes Vajda mentioned in his reading list, several contain reproductions that may have offered models for Icon Self-Portrait Pointing Upward, images that have thus far remained unmentioned in Vajda-related literature. In Oskar Wulff's book Early Christian and Byzantine Art, for example, published in 1914 and to be found in Vajda's list, there is a reproduction of an icon, most resembling a memorial or death portrait, depicting the Syrian martyrs Saints Sergius and Bacchus (Figure 5); the outerwear thrown over their shoulders (even the creases of its drapery, formed from fine lines) is comparable to the fabric thrown over the shoulder of Vajda's spherical figure. ${ }^{46}$ In this icon Christ is the giver of eternal life; his face framed in coin-like fashion is enveloped in a halo, which does not fuse with the martyrs' glory, just barely touches them. The three figures are, however, unified by a darker contour. The

45) It should be noted that this reading has been questioned. See Petőcz, 'A Felmutató titkai.'

46) The volume is included in Vajda's reading list. The list is published in Radák, Vajda Lajos Pepita füzetei, 139. Oskar Wulff, Altchristliche und Byzantinische Kunst I. Die Altchristliche Kunst, Berlin - Neubabelsberg: Akademische Verlagsgesellschaft Athenaion, 1914, figures 286 and 308. 


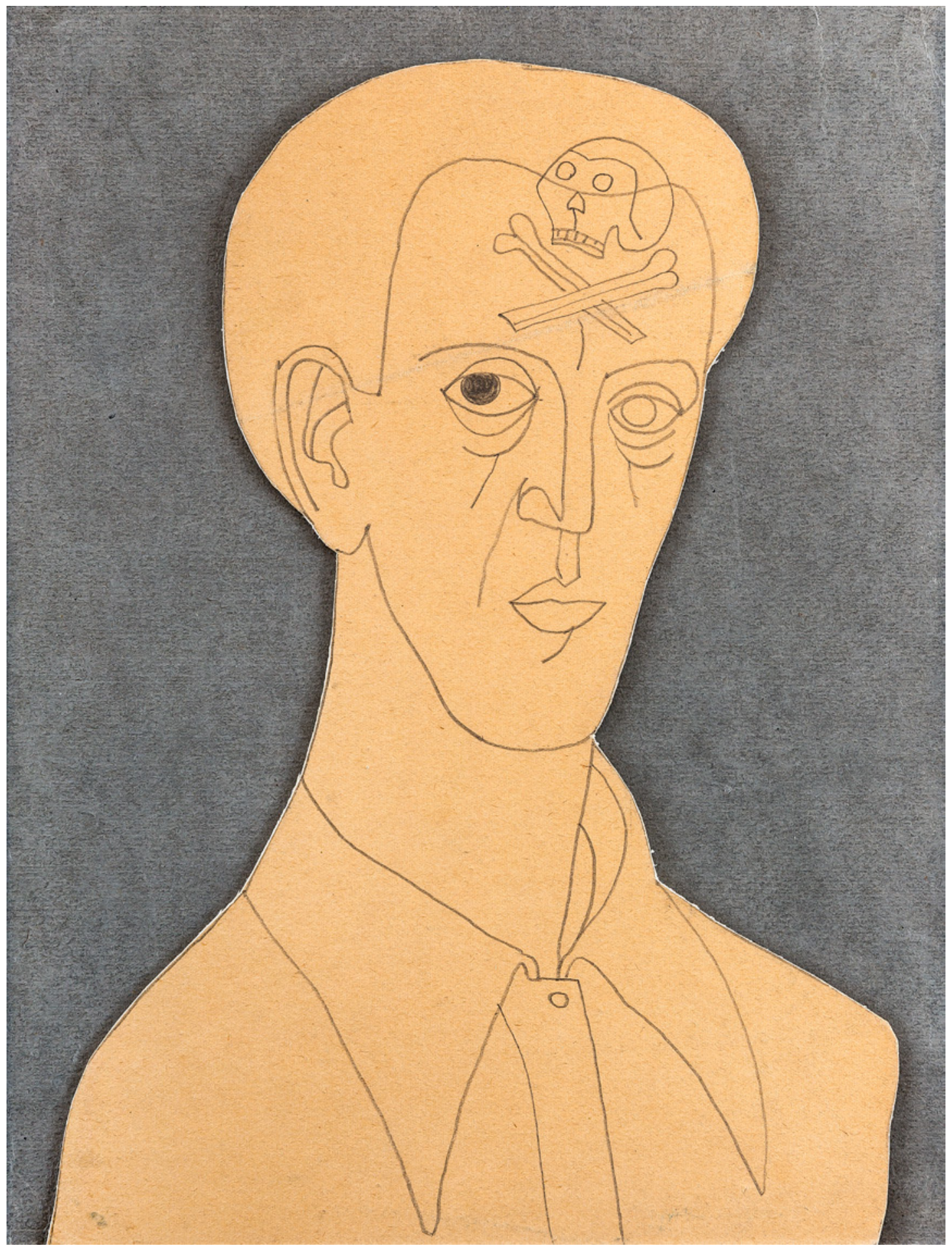

Figure 4: Lajos Vajda: Self-Portrait with Skull, 1936. Pencil and collage on paper, 32 × 25,5 cm. Szentendre: Ferenczy Museum Centre. 


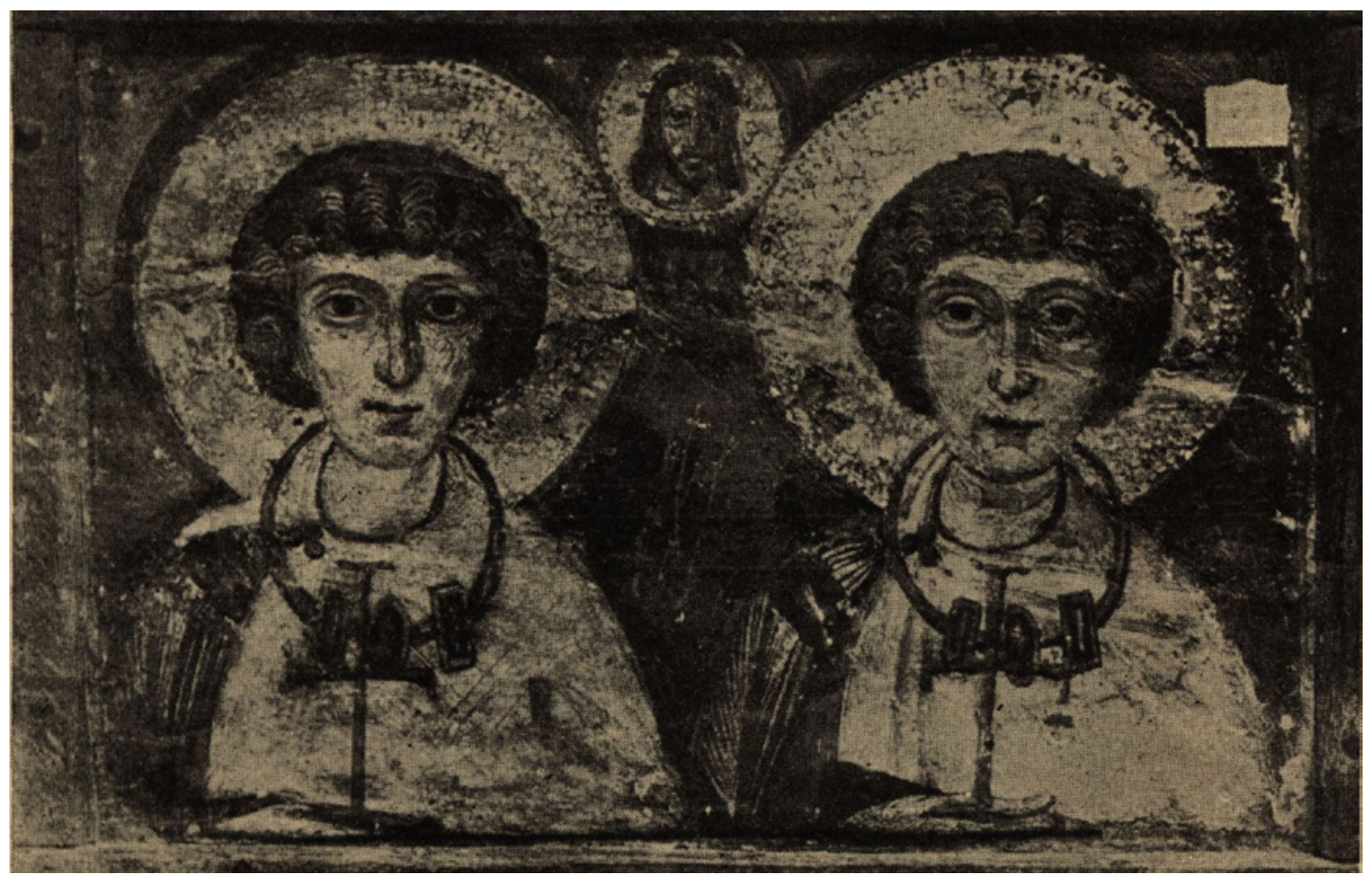

Figure 5: Reproduction of Icon Saint Sergius and Bacchus.

From Oskar Wulff, Altchristliche und Byzantinische Kunst, Berlin-Neubabelsberg: Athenaion, 1914.

triadic nature of the portrait is even more significant here (although drawing a formal analogy form would be less appropriate): the dual portrait is complemented by the nimbus-framed face of Christ, whose presence alludes to the martyrdom of the saints.

There is also a formal similarity with a further work reproduced in the volume by Wulff, namely, an ivory miniature of three Latin Church Fathers (Figure 6), in terms of both the gesture of the right hand of the middle figure imparting a blessing, as well as its place in the composition. The hand, which is parallel to the image plane, is intersected by the lower edge of the image surface, as if it belonged not to this figure, but to some other person. In Vajda's work, too, it seems apparent that the hand belongs not to the self-portrait-like or icon-like figure, but to someone else. The 1925 edition of Wulff and Alpatoff's Monuments of Icon Painting in the History of the Church is repeatedly listed in Vajda's reading list. ${ }^{47}$ In a Deésis-type icon featured in this book, which depicts full-length portraits of both Saints Peter and Paul (Figure 7), the hand pointing to Christ and Christ's halo-enveloped face is placed at the ideological centre, the central axis, of the image field. The triple nature of these representations, along with the Christ-image attached to the portrait and attesting to Christ's incarnation, alludes to the relationship between human and God, and the divine essence inherent in all that is human.

The icons featured in the book by Wulff and Alpatoff show the face and the hand conveying theological content: the dogma of God's incarnation. In this way, the hand pointing upward

47) Oskar Wulff and Michael Alpatoff, Denkmäler der Ikonenmalerei in Kunstgeschichtlicher Folge, Hellerau bei Dresden: Avalun-Verlag, 1925, figures 25 and 71. 


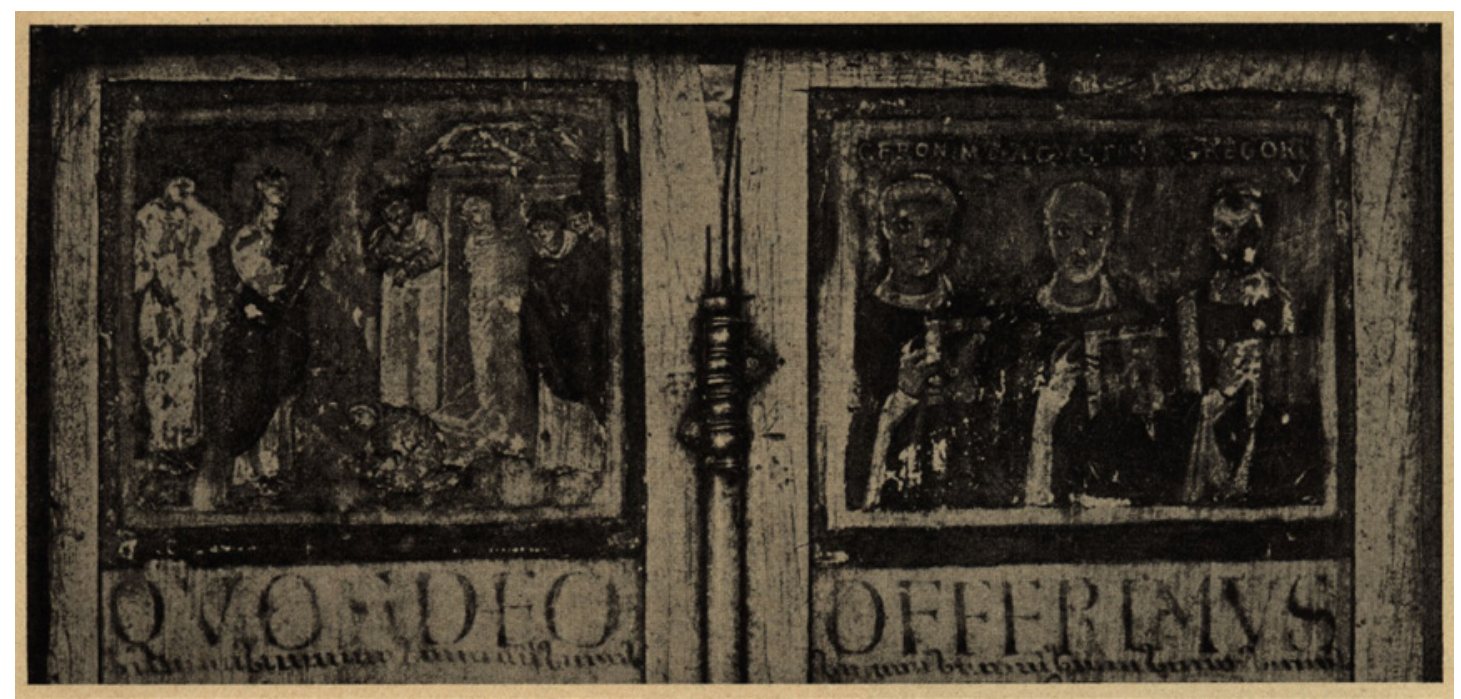

Figure 6: Reproduction of miniature of Three Latin Church Fathers.

From Oskar Wulff, Altchristliche und Byzantinische Kunst, Berlin-Neubabelsberg: Athenaion, 1914.

alludes to the divine. Vajda essentially reduces the image to these elements: the face and the hand. The body is absent, the clothes are only tentatively present, evoking a sense of uncertainty, the contours of the hair are shifting. It is, in fact, the idea of 'incarnation' that is absent from the image, and it can be compared with Vajda's Icon Self-Portrait from 1936 (Figure 2), where the white dots of the clothing against dark blue indicate a transcendent character for the figure. In these examples of icon painting, the external figure of Christ is always positioned higher in relation to the other figures, while, in Vajda's case, the face that takes shape and disappears in the middle is not elevated. That is to say, a vertical hierarchy does not manifest itself here, and no distinction is made between aspects belonging to the heavenly and earthly spheres. Consequently, the hand, too, becomes larger and cannot be pointing upward, as there is nothing in the heavenly realm to point to. In examples of icon painting where the figure is portrayed in full, the emphatic bareness of the feet symbolises one's connection to the human sphere. In accordance with this type, in the full-length depictions of Deesis, the book in Christ's left hand is positioned lower down than his shoulder, while his upward pointing right hand is held higher than the volume.

Vajda uses a half-figure: like the historic examples mentioned above, the hand with the ring finger and thumb touching is positioned higher; it is comparable to the seventeenth-century icon of Christ Pantocrator in the Serbian Ecclesiastical Art Collection of Szentendre. In Icon Self-Portrait from 1936 (Figure 2), the body 'begins' around the waist, while the figure - or figures - in Icon Self-Portrait Pointing Upward (Figure 1) is cut off by the bottom edge of the image field higher up the torso. In Vajda's painting Christ's hand gesture also differs from that we customarily see in the icons. Where, in icon paintings, Christ, by touching together his thumb and his ring finger, forms a circle as the symbol of the heavenly domain, signifying unity and the universe (alpha and omega), in Vajda's work, the two fingers do not actually touch: the unique hand gesture not only contradicts the icon, it also brings its being into 


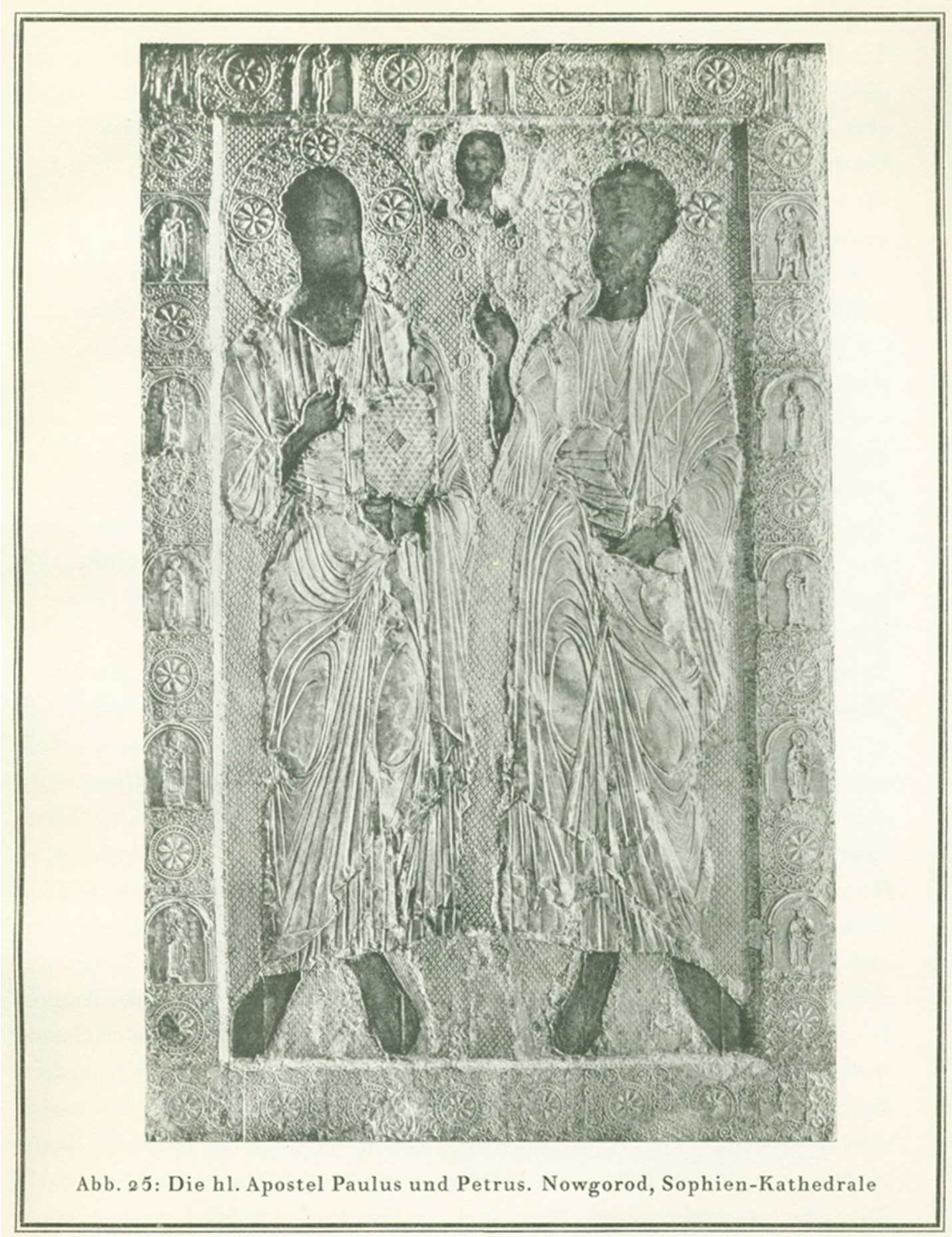

Figure 7: Icon of Peter and Paul.

From Oskar Wulff and Michael Alpatoff, Denkmäler der Ikonenmalerei in Kunstgeschichtlicher Folge, Hellerau bei Dresden: Avalun Verlag, 1925. 
question; instead of pointing upward, it points to the portrait and emphasizes the determining character of the representation.

The icon, as an expression of transfiguration and metamorphosis, signifies the incarnation that has been accomplished, rather than focusing on the process. In contrast, in Vajda's work, it is transformation; the bidirectional process - the here and now - and the process of incarnation that is being depicted. This also comes through in the complex, enigmatic and reality-defying relationships between the different layers of the head and the upper body.

In Vajda's oeuvre, we can find several other examples where the head (portrait) is represented together with the hand. Yet the hand motif used in Icon Self-Portrait Pointing Upward does not appear anywhere else in the surviving material of his oeuvre. In a charcoal drawing from 1934 entitled Head Study, four fingers of the left hand with pointed ends are visible; the index finger is separate from the others and follows the jaw line. ${ }^{48}$ Friends (1937), Double Self-Portrait with House (1937) and Head in Palm with Saw Pattern (1937) all repeat the motif of the hand and face touching. In Unshaven Self-Portrait from 1937 (Figure 8), four fingers on the figure's right hand point downward, or his hand is supported by a flat surface, with only two fingernails visible. ${ }^{49}$ In interpreting the hand motif of Self-Portrait Pointing Upward, however, Vajda's interest in icons may hold the key; namely the fact that icons are traditionally 'not created by hand.' Vajda did not sign or give a title to any of his works. In this particular piece, however, it is precisely by drawing a distinction between this and icons that the emphatic and exaggerated appearance of the hand (both in terms of its forms and proportions) gains meaning: with its three open fingers, in referring to the trinity of the heads, it repeats the darkness of the figure disappearing in the middle.

\section{Conclusion}

Given these formal analogies and disparities, as well as Berdyaev's dualistic conceptualisation of culture that shaped Vajda's 'Szentendre Programme,' we can state that in Icon Self-Portrait Pointing Upward, the 'head' that is represented from the front while also seen turning to the side, signifies diverging modes of conceptualising and representing human being. Since the painting and the Szentendre Program occupy key positions in Vajda's oeuvre, as well as in Hungarian art history, it is important to determine their possible sources. This analysis, which highlights the significance of Berdyaev's ideas along with a closer reading of the Russian philosopher's texts, offers new points for consideration, potentially enriching existing interpretations of this painting. In fact, Berdyaev's influence on Vajda was limited to a specific period in his career; the hopes he expressed in the 'Szentendre Programme' seem to have dissipated - although the reasons have never become clear - and we don't find clear continuance in the artist's oeuvre. Nevertheless, Berdyaev and Russian existentialist philosophy remained an often-referenced popular source of ideas in Hungary, although this was mostly limited to philosophical circles, including figure such as Lajos Szabó and Béla Tábor.

48) Petőcz and Szabó, eds, Vajda Lajos. Világok között, 85, figure 87.

49) Ibid., 18, figure 8. 


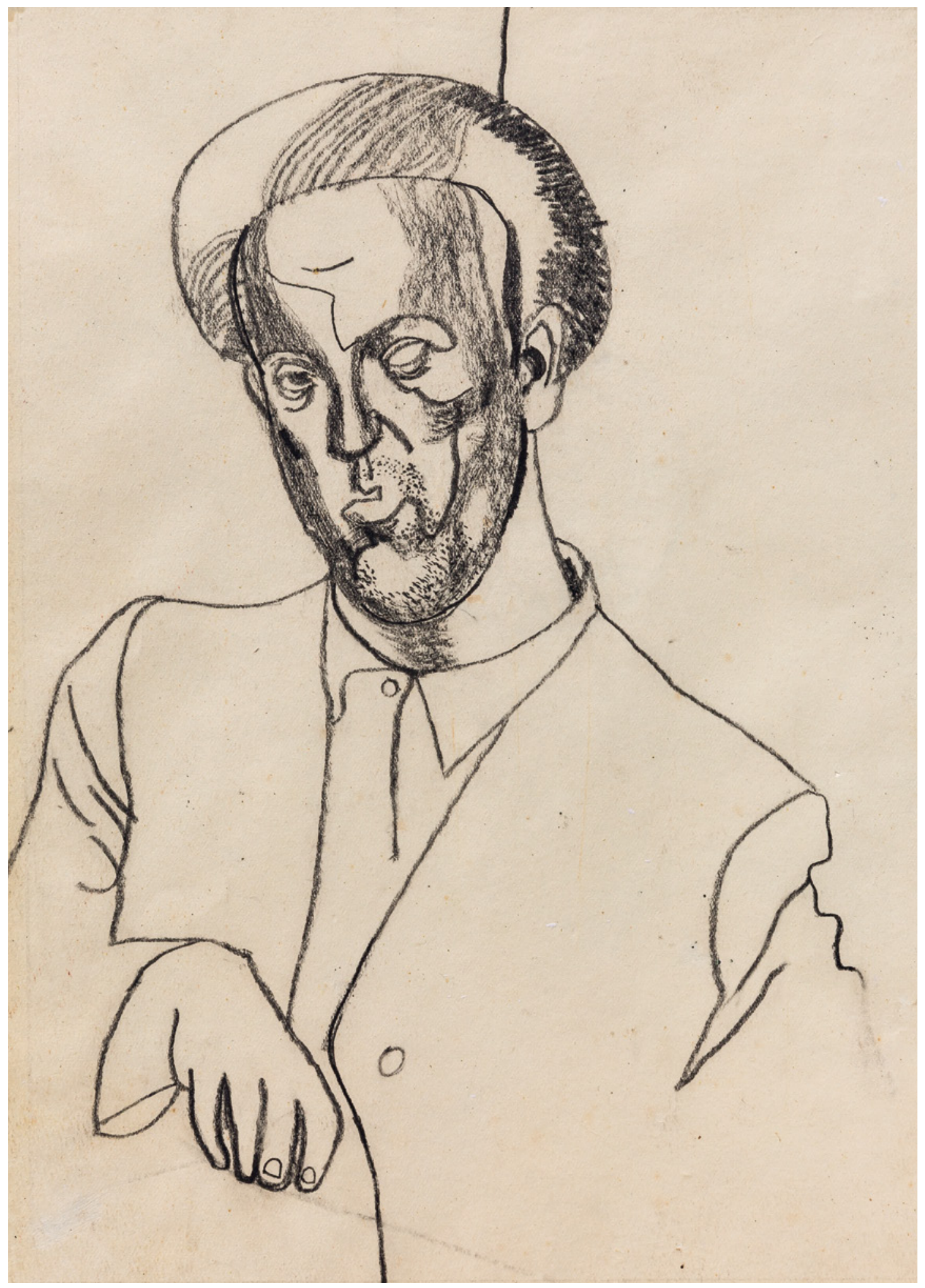

Figure 8: Lajos Vajda, Unshaven Self-Portrait, 1937. Pencil on paper, 30 x 22,2 cm. Szentendre: Ferenczy Museum Centre. 
Finally, one might argue that Vajda's Icon Self-Portrait Pointing Upward is not about (to once again reference Bakhtin) sounding a single voice. Instead, on account of its universal nature, seeking synthesis, and thus experiments with new possibilities of pictorial representation, it has the capacity of articulating multiple philosophical and theological thoughts. The figure disappears and reappears; it could be the right hand, or the left. With his lines that form and transform into one another, Vajda, by continuously opening closed forms, represents a multidirectional process. This article has not been an attempt to cut the Gordian knot of interpretation by offering this reading alone. It leaves the door to further interpretations open, even if, drawing on the biographical data, preserved sources, and the dichotomous and synthesising principle espoused by the 'Szentendre Program,' the Berdyaevian reading seems most obvious. Had the artist left his work untitled we might regard it quite differently today. Vajda, however, was never interested in 'illustrating' some thesis or idea; starting with his Paris montages, his focus was always on juxtaposition, on piecing together - and, thus, on modification - in both a formal and conceptual sense. For this reason, and in spite of the fact that the painting was created at a time when the Hungarian government espoused a nationalist-Christian state, for Vajda, thinking renewed through Berdyaev's Eastern Christianity was meaningful not as a political programme, but rather as a cultural and artistic vision. 